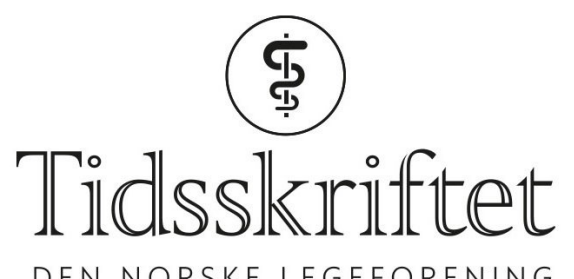

DEN NORSKE LEGEFORENING

\title{
Mondors sykdom - ikke så sjelden
}

KOMMENTAR

\section{GUDJON L. GUNNARSSON}

E-post: gulgun@sthf.no

Gudjon L. Gunnarsson er overlege og plastikkirurg.

Ingen oppgitte interessekonflikter.

Jeg takker forfatterne for tydelig å fremheve den interessante Mondors sykdom i Tidsskriftet (1). Dette er, som de nevner, en overflatisk thromboflebitt, hovedsak av mekanisk årsak. Langvarig kompresjon av superficielle epigastriske vener i inframammar-furen fører til at de tromboserer, hvis ikke veneklaffene gir seg (som igjen er grunnen til at tilstanden forekommer forholdsvis sjeldent). Tilstanden oppdages ofte 3-4 uker etter skade eller operasjon når organisering av thromben er underveis og hevelsen forsvinner. Arrkontraksjon gir en smertefull streng svarende til den obstruerte venen.

Innenfor plastikkirurgi og brystkirurgi er Mondors sykdom nok så velkjent i forbindelse med forskjellige operasjoner på bryst, og ifølge litteraturen er insidencen $1 \%$ (1,07\% for estetiske brystforstørrelser og o,96\% for onkologisk brystkirurgi) $(2,3)$. Tilstanden hverken rapporteres eller forskes på, ettersom den ikke er farlig og behandlingen er som beskrevet konservativ og symptomlindrende.

\section{LITTERATUR:}

1. Nordlie H, Tangerud Å, Thorsnes SE et al. Mondors sykdom. Tidsskr Nor Legeforen 2018; doi: 10.4045/tidsskr.18.oog1. [CrossRef]

2. Hou MF, Huang CJ, Huang YS et al. Mondor's disease in the breast. Kaohsiung J Med Sci 1999; 15: 632 9. [PubMed]

3. Khan UD. Incidence of mondor disease in breast augmentation: a retrospective study of 2052 breasts using inframammary incision. Plast Reconstr Surg 2008; 122: 88e - ge. [PubMed][CrossRef]

Publisert: 25. juni 2018. Tidsskr Nor Legeforen. DOI:10.4045/tidsskr.18.0476

(C) Tidsskrift for Den norske legeforening 2020. Lastet ned fra tidsskriftet.no 